\title{
Microeconomic Analysis for the Formation of Renewable Energy Support Policy: the Case of wind Power Sector in Lithuania
}

\author{
Valentinas Klevas, Viktorija Bobinaite, Mantas Marciukaitis, Dalius Tarvydas
}

\author{
Lithuanian Energy Institute \\ Breslaujos st. 3, LT-44403, Kaunas, Lithuania \\ E-mail.valentinas.klevas@lei.lt,viktorija.bobinaite@lei.lt,mantas.marciukaitis@lei.lt,dalius.tarvydas@lei.lt \\ cross $^{\text {ref }}$ http://dx.doi.org/10.5755/j01.ee.29.2.13626
}

\begin{abstract}
Economic research of renewable energy sources (RES) intensified in recent years through implementation of the European Union Directives and the following Regulations. Incentives for wider use of RES are declared both in the European Union and in Lithuanian laws. However, it may be stated that there is lack of research, which would give answers to questions on economic assumptions that would link energy policy to economic results and would justify benefits of the use of RES technologies on a national scale. Thus, this paper aims at presenting methodological principles of wind power technologies assessment based on economic indicators. The impact of wind power technologies implementation on the economy was estimated based on microeconomic analysis method. Levelised cost of energy approach was used to compute wind power prime cost. Economic indicators were computed. The research results disclosed that investment subsidy and feed-in tariffs are attractive support measures for the investor. They could be used to promote wind power sector development in Lithuania in the future. Energy policy decision making should be based on the economic assessment principles. Wind power support schemes and support levels should be reconsidered taking into account the net benefits of wind power technologies. Wind power technologies are beneficial to economy due to their impact on profit, income-based taxes, electricity import substitution and CO2 savings.
\end{abstract}

Keywords: Wind Energy; Support Measure; Microeconomic Analysis; Economic Indicators; Levelised Cost of Energy.

\section{Introduction}

The aim of the research is to apply the approach enabling the assessment of external benefit for the use of renewable energy sources (RES), which is usually not assessed for individual projects. Support measures for the use of RES often contradict market patterns due to shortterm period goals, which are one of the main shortages in nearly all countries (Ciarreta et al., 2011; European Commission, 2014).

According to authors of the paper, each country has different starting conditions, namely, developed technical infrastructure and own volumes of energy resources, however, the development of energy from RES should be shaped on the basis of a long-term macroeconomic policy (EC, 2013). This means that among other actions, a good and scientifically based theoretical background is needed, i.e. indicators of economic development and method for assessment of impact of a certain type of energy from RES on these indicators are required. This paper deals with these issues. Namely, the authors aim at proposing the microeconomic analysis method (taking into account the economic benefits for the developer), utilizing the external parameters, when assessing RES support measures. It is assumed that results obtained in a single project analysis could be further extrapolated to assess possible impact of the support measure at macroeconomic level.

Lithuanian wind power sector was chosen for the analysis. Motivation for this choice originates from the peculiarities and oneness of energy sector and its regulation (including support measures) in the country.
Lithuania as a case study was examined considering the fact that energy from RES is supported through timevarying support measures (investment subsidy, feed-in tariff, fiscal measures and a combination of them) which basically repeat instruments and financial mechanisms that are used in foreign countries without a deeper understanding of cost and benefits of such support measures. Moreover, it was observed that RES support measures applied in the country do not encourage project developers to choose economically optimal technologies, and often unreasonably expensive plants are installed, operational rates of which are not always justified. The main deficiency of this type of promotion is lack of connection with the achievement of results. Thus, this paper introduces to the reader the theoretical background of economically efficient RES support measures. Wind power sector was selected for the analysis considering the benefits wind power provides (EWEA, 2009).

\section{Theoretical Background}

As literature analysis shows, a need to assess RES support measures arises from the observation that RES support measures not only increase cost but also give benefits for the country's economy. These costs and benefits are realized through various channels and interrelationships. The interrelationships between RES sector and economy are rather complicated, but their identification and assessment are essential seeking to improve RES support policy, increase its efficiency and achieve net benefits at country's level. 


\section{Impact of RES Sector Development on the Macroeconomic Indicators}

Most of the authors who analyzed the impact of the growth of RES utilization on the economy had concluded a positive impact on GDP growth as well as on improving the employment and trade balance. This is reflected in articles of T. Chien and J. L. Hu (2007, 2008), J. Domac et al. (2005), J. Blazejczak et al. (2011) and other scientists. T. Chien and J. L. Hu (2007) showed a positive correlation between the consumption of RES and the improvement of macroeconomic indicators. In his later work, the authors Chien \& Hu (2008) found that the development of RES technologies has had a major impact on capital formation. This conclusion was made by analyzing 116 economies using the Structured Equation Model (SEM). J. Domac et al. (2005) assumed that an increased use of renewable resources has encouraged the creation and development of local business, establishment of new jobs (both in RES and related fields) and changed imported fuel, which has improved the trade balance. This opinion was endorsed by Blazejczak et al. (2011), which examined the development of the RES sector in Germany in the long-term (up to 2030) perspective. The development of the RES will have a positive impact on the German economy (its employment, local business development and GDP). In addition, the traditional energy-related sectors of the economy will be transformed. Data on GDP, capital, labour and energy from renewable sources in the individual regions of Italy between 1997 and 2007 also showed positive developments in the use of RES (Magnani $\&$ Vaona, 2013). They found that energy produced from RES improves labour and capital productivity, reduces the dependence of regions on fossil fuel price volatility, reduces the negative impact on health and the environment.

\section{Bilateral Relationship between RES and Macro Economy}

Research was conducted to determine the economic factors affecting the development of the RES sector by Ting-Huan Changa, et al., (2009); Sadorsky, (2009a); Sadorsky, (2009b). Studies have shown that there was a positive causal link between RES development and economy in the OECD countries. This suggests that economic growth can be used realistically for the development of RES-technologies. Sadorsky (2009a) found that the increase in real incomes per capita had a positive impact on the increase in RES utilization. In the long run, when real GDP per capita increases by $1 \%$, then the RES consumption per capita increases by about $3 \%$. However, the results of the research revealed that there is a reciprocal relationship between the price of electricity and the volume of consumption of RES. An extremely sensitive study by Sadorsky (2009b) in the G7 countries assessed the relationship between RES and real income, CO2 emissions and oil in 1980-2005. The author calculated the results of a positive elasticity between the volume of consumption of RES and income, CO2 emissions and oil prices. Regardless of the test method used, the results were similar.
Serious research in analyzing the mutual influence of the broader use of RES on various macroeconomic indicators were published by Y. Fang (2011), E. Yildirim et al. (2012), N. Apergis and J. E. Payne (2010a, 2010b, 2011) Menegaki (2011), U. al-Muli et al. (2013).

E. Yildirim et al. (2012) examined the relationship between GDP and renewables and their types, such as energy from biomass, wood and waste, geothermal and hydropower in the USA in 1949-2010. The results of the research showed that there are statistically significant relationships between GDP and RES. Analyzing Chinese data, Y. Fang (2011) found that the share of renewable resources in the fuel and energy consumption structure is one of the key factors contributing positively to the economic asset of the nation and the individual. It takes place through capital formation and technological progress and other factors that have a positive effect on the economy. Estimates of RES revenue elasticity indicators have shown that the development of renewable energy sources in villages can increase the population's income more than the development of renewable energy sources in cities.

N. Apergis and J. E. Payne (2010a, 2010b, 2011) analyzed data on 6 Central American countries from 1980 to 2006, 20 OECD countries in 1985-2005 and 13 countries in Europe and Asia in 1992-2007. The study found that the relationship between GDP, gross fixed capital formation and RES is bilateral. This led to the conclusion that, in a shorter period, the wider use of RES has affected GDP through its component, called "gross fixed capital formation". Apergis and Payne (2012) have studied 80 economically developed and developing countries, including research of the use of RES and fossil fuels. The results of the research showed that during the period of 1990-2007 traditional energy sources and RES have had a positive impact on GDP, while changes in GDP have influenced changes in fuel and energy costs. The calculated elasticity of fossil fuel and RES on GDP development was very similar. This has shown that regardless of the consumption of resources, impact to GDP is similar. Therefore, conventional statistical methods have weaknesses. U. al-Mulali et al. (2013) carried out a peer-topeer analysis of RES-E and economic growth in 108 countries with very different GDP. It was found that in $80 \%$ of countries there is a bilateral relationship between RES consumption volume and GDP. This is especially true for high-income countries. Menegaki (2011) analyzed the EU27 countries. This author estimates that, in the long run, increase in the use of renewable energy sources have had a direct impact on the GDP of EU-27. Similar conclusion was made by Bobinaite at al. (2011) on the basic assessment of causality relationship between renewable energy consumption and economic growth in Lithuania.

\section{Shortcomings of Previously Performed Research and Suggestions for the Methodology Preparation}

Statistical research methods do not allow to distinguish the essential advantages of RES against fossil fuels. In order to level competition opportunities for generating energy from RES and fossil fuel, a specific problem should be solved that is still hardly perceived and rarely analysed in economic theory. This problem is the concept of 
external public benefit, which is difficult to assess and repay for producers, who implement the "mission" of the use of RES technologies at their own risks. Tremendous possibilities to foster RES (especially solar, wind, and geothermal energy) implementation process lay in this field. Social benefit is usually assigned to business; however, profit is the main motivation for business and not social needs of population, and certainly not meeting energy needs of future generations. Consumers can be motivated by indirect subsidizing. Therefore, benefit is understood as lesser impact for environment, also solving of some social problems, however, in practice the use of RES deals with significant problems (Klevas, 2015).

According to the authors, such assessment is inseparable from the microeconomic analysis of the project. Results obtained in a single project analysis could be interpolated to assess possible impact of the support measures at macroeconomic level.

Thus, the authors propose the microeconomic analysis method for assessment of economic cost and benefits of RES support measures. Based on this analysis conclusions were drawn on how to form RES support policy.

\section{Methodology}

\section{Description of the Research Object}

Lithuania promotes production of wind power through support measures. The support is differentiated based on the installed capacity of WPP. Three support levels are available. This is support to WPP with the installed capacity of more than $350 \mathrm{~kW}, 10-350 \mathrm{~kW}$ and up to $10 \mathrm{~kW}$.

WPPs with the installed capacity of more than $350 \mathrm{~kW}$ make the majority in Lithuania. They are mainly built as stand-alone high-power units (from 600 to $2000 \mathrm{~kW}$ ) or as wind farms consisting of several WPPs (from 2 to 19 units). Wind farms with more than 100 WPPs are in the planning stage. As the world's wind energy future is associated with the development of multi-megawatt WPPs, manufacturers' supply of this category of equipment is large and there is a possibility to choose from more than ten largest producers. The Enercon is the leader in WPP market in Lithuania. These WPPs are relatively expensive, but they have proven their reliability and efficiency in moderate winds, therefore they gained popularity in Lithuania. The Enercon type WPP was taken for the analysis.

The number of WPPs with the installed capacity from $10 \mathrm{~kW}$ to $350 \mathrm{~kW}$ has been increasing during recent years. The reason for this is the Law on Renewable Energy Sources (2011). It allows the simplification of conditions for WPP projects of the installed capacity from $10 \mathrm{~kW}$ to $350 \mathrm{~kW}$. Supply of this category WPPs is small in the market. Investors usually choose from several options, such as new (Enercon E33, Vergnet GEV MP, SIVA $50 / 250$ ) or second-hand wind turbines (Bonus, WindWorld, DanWind, Vestas etc.). The choice is usually determined by the amount that could be available for the investment and investors' estimates. The cost of a new WPP may be more than twice higher than that of the refurbished WPP. However, they produce more energy and require less maintenance, therefore operating costs are significantly lower. Selection of the refurbished WPP could reduce initial investments, but they produce less energy (an older technology, WPP had been used for up to 20 years), also maintenance is more expensive, and the project has higher risk. The most popular new WPPs in this category are $330 \mathrm{~kW}$ Enercon E33, which have a maximum power limited to $250 \mathrm{~kW}$ during the operation. The reason for limitation is the fact that permits to expand the capacity of power generation had been obtained and EIA (Environmental Impact Assessment) procedures had been made before the new Law on Renewable Energy Sources (2011) and implementing legislation came into force, which changed maximum power limit from $250 \mathrm{~kW}$ to $350 \mathrm{~kW}$. Therefore, installed capacity of E33 WPP unit results in relatively high price, about $1900 \mathrm{EUR} / \mathrm{kW}$, in comparison with the prices of other producers.

For small wind turbines, up to $10 \mathrm{~kW}$, there is a separate support scheme. According to the procedure and conditions prescribed by the Government, excess electricity produced in up to $10 \mathrm{~kW}$ capacity WPP must be obligatorily purchased at a fixed feed-in tariff. Excess electricity is recognized as not more than $50 \%$ of produced electricity using RES during the calendar year. Permission for the expansion of such capacity electricity's generation is unnecessary, if electricity is produced only for individual use and needs of the household. Producers, who foresee the development of up to $10 \mathrm{~kW}$ electricity production capacity and who produce electricity only for their own use and needs of the household, must notify the electricity network operator according to the procedure of Government or its authorized institution. According to the Lithuanian distribution network operator data, only several wind turbines withcapacity up to $10 \mathrm{~kW}$ have been officially installed in Lithuania so far.. According to the small wind power market participants there are several hundreds of $\mathrm{kW}$ of small wind turbines installed in Lithuania with total capacity exceeding $320 \mathrm{~kW}$, but they are not connected to the grid. Sales of excess electricity for the electricity network is a new scheme, therefore society feels lack of information about technical possibilities and economic benefits of such system installation. Estimations and demonstration projects are necessary because they are able to prove that such system needs no batteries, which typically comprise up to half of the total project cost.

\section{Method of the Research}

\section{Method for Levelised Cost of Energy Estimation}

Levelised cost of energy (LCOE) is one of the most popular approaches for comparison of different energy generation alternatives on equal basis. Present value of total life-cycle cost is calculated considering chosen discount rate and allocated per one unit of energy. The LCOE is utilized to assess competitiveness of different energy generation options, quantifying possible gains for the project developer. The elaborated LCOE approach, which was presented in (Bobinaite \&Tarvydas, 2014; Klevas, 2015), gives an opportunity to quantitatively assess the influence of certain RES support measures on cost of energy production. It provides investor with a tool which could be used to compare different RES investment projects. 
Valentinas Klevas, Viktorija Bobinaite, Mantas Marciukaitis, Dalius Tarvydas. Microeconomic Analysis for the Formation ...

Modified LCOE extended with external data enables to evaluate economic effects. An extended LCOE approach is described by Equation (1):

$$
L C O E=\frac{\sum_{t=0}^{T} \frac{I_{t}+O \& M_{t}+F_{t}-P T C_{t}-I T C_{t}-E T S_{t}}{(1+d)^{t}}-\frac{R V}{(1+d)^{T}}}{\sum_{t=0}^{T} \frac{C_{I} \cdot 8760 \cdot L F \cdot(1-D R)^{t}}{(1+d)^{t}}}
$$

where: $\quad I_{t}$-investment cost at time step t, EUR; $O \& M_{t}-$ operation and maintenance cost at time step t, EUR; $F_{t}$ - fuel cost at time step t, EUR; $P T C_{t}-$ subsidy for energy production, EUR; $I T C_{t}$ - investment subsidy, EUR; $E T S_{t}$ - income / cost for emission allowances, EUR; $R V-$ residual value, EUR; $C_{I}$ - installed capacity, $\mathrm{kW}(\mathrm{MW})$; $L F$-load factor, $\% ; d$-discount rate, $\% ; t$-life time, years; $D R$ - degradation rate of technology, $\%$.

\section{Method for Estimation of Electricity Import Substitution to Domestic Production}

Taking into account, that electricity produced by WPP substitutes imported electricity, an import substitution was computed based on the Equation (2):

$$
\begin{aligned}
& S_{\text {import }}=\sum_{t=0}^{T}\left(\frac{C_{I} \cdot 8760 \cdot L F \cdot(1-D R)^{t}}{(1+d)^{t}} E_{t}\right)- \\
& \left(\sum_{t=0}^{T} \frac{I_{t} S_{t}^{I}+O \& M_{t} S_{t}^{v}+F_{t} S_{t}^{F}}{(1+d)^{t}}\right)
\end{aligned}
$$

where: $\quad S_{\text {import }}-$ electricity import substitution, $E_{t}-$ price of the electricity in the spot market at time step t, $S_{t}^{I}$-share of import in the investment cost at time step t, $S^{v}{ }_{t}$ - share of import in the O\&M cost at time step t, $S^{F_{t}}$ share of import in the fuel cost at time step t.

\section{Method for Estimation of Profit}

Profit of WPP was computed based on the Equation (3):

$$
\begin{aligned}
\Pi= & \sum_{t=0}^{T}\left(\frac{C_{I} \cdot 8760 \cdot L F \cdot(1-D R)^{t}}{(1+d)^{t}} P_{t}\right)- \\
& \left(\sum_{t=0}^{T} \frac{I_{t}+O \& M_{t}+F_{t}-P T C_{t}-I T C_{t}-E T S_{t}}{(1+d)^{t}}-\frac{R V}{(1+d)^{T}}\right)
\end{aligned}
$$

where: $\Pi$-profit of WPP, $P_{t}$-price of the energy sold (feed-in tariff) at time step t.

\section{Method for Estimation of Income-Based Taxes}

Income-based taxes of WPP were computed based on the Equation (4):

$$
T_{I B}=\left(\sum_{t=0}^{T}\left(\frac{I_{t} L_{t}^{I}+O \& M_{t} L_{t}^{v}+F_{t} L_{t}^{F}}{(1+d)^{t}}\left(\frac{d_{i}+d_{e}+d_{f}+d_{k}}{1+d_{f}+d_{e}}\right)\right)\right) \text { (4) }
$$

where: $\mathrm{T}_{I B}$ - income-based taxes, $L_{t}^{I}$ - share of labour in the investment cost at time step t, $L_{t}^{v}$ - share of labour in the O\&M cost at time step $\mathrm{t}, L^{F}{ }_{t}$ - share of labour in the fuel cost at time step $\mathrm{t}, d_{i}$-social security tax paid by employee, $d_{e}$-social security tax paid by employer, $d_{f}-$ payment to the guarantee fund, $d_{k}$ - personal income tax.

\section{Method for Estimation of $\mathrm{CO}_{2}$ Savings in Monetary Terms}

$\mathrm{CO}_{2}$ savings were computed based on the assumption that electricity produced by WPP will replace gas-based electricity generation. $\mathrm{CO}_{2}$ savings are described by the Equation (5):

$$
C O_{2, M}=\sum_{t=0}^{T}\left(\frac{E F_{g} \cdot C_{I} \cdot 8760 \cdot L F \cdot(1-D R)^{t} \cdot E T S_{t}}{e_{g} \cdot(1+d)^{t}}\right)
$$

where: $\mathrm{CO}_{2, M}$-savings of $\mathrm{CO}_{2}$ emissions, EUR, $E F_{g}-\mathrm{CO}_{2}$ emission factor for natural gas, $\mathrm{kg} / \mathrm{kWh}, e_{g}-$ efficiency of gas $\mathrm{PP}$, which is 0.58 .

\section{Data and Cases Analysed}

The research presented in the paper is based on the economic and technological data of WPP. These data are provided by the Laboratory for Renewable Energy and Energy Efficiency at Lithuanian Energy Institute, Nord Pool Spot AS and were collected from the scientific literature.

Four cases for a certain category of WPPs are analysed. The first case is a reference case. It gives estimations of LCOE, profit and income-based taxes if no support is provided to a certain WPP. The second case assumes that a new support scheme is applied. This is a 30 $\%$ investment subsidy for a WPP. The third case takes into account a $50 \%$ investment subsidy for a WPP. The fourth case considers that presently existing support scheme is further used and a maximum feed-in tariff that is approved

\begin{tabular}{|c|c|c|c|c|c|}
\hline \multirow{2}{*}{\multicolumn{2}{|c|}{ Variable }} & \multicolumn{4}{|c|}{ The category of WPP } \\
\hline & & \multirow{2}{*}{$\begin{array}{c}\text { More than } 350 \mathbf{~ k W} \\
2000\end{array}$} & \multicolumn{2}{|c|}{$10-350 \mathrm{~kW}$} & \multirow{2}{*}{$\frac{\text { Up to } \mathbf{1 0} \mathbf{k W}}{10 / 4}$} \\
\hline \multirow{3}{*}{ Technical } & Electric capacity, $\mathrm{kW}$ & & $\begin{array}{l}250 \text { (new } \\
\text { WPP) }\end{array}$ & $\begin{array}{c}250 \text { (refurbished } \\
\text { WPP) }\end{array}$ & \\
\hline & Maximum load factor, $\%$ & 32 & 25 & 23 & $21 / 20$ \\
\hline & Lifetime of WPP, years & 25 & 25 & 20 & 20 \\
\hline \multirow{4}{*}{ Cost } & Investment cost, thousand EUR & 3000 & 464.25 & 311.250 & $15.00 / 8.11$ \\
\hline & Fixed cost, EUR/kW a year & 15.00 & 18.57 & 12.45 & $15.00 / 20.28$ \\
\hline & Variable cost, EUR/MWh & 0.29 & 0.29 & 0.29 & 0.29 \\
\hline & Fuel cost, EUR/MWh & 0.00 & 0.00 & 0.00 & 0.00 \\
\hline
\end{tabular}
by the National Control Commission for Energy and Prices (NCCEP) for a certain category of WPP is provided for each kWh of electricity supplied to the electricity grid. Data for the computations are provided in Table 1.

Table 1

Inputs for the Estimation of LCOE, Profit and Income-Based Taxes 


\begin{tabular}{|c|c|c|c|c|c|}
\hline \multirow{2}{*}{\multicolumn{2}{|c|}{ Variable }} & \multicolumn{4}{|c|}{ The category of WPP } \\
\hline & & \multirow{2}{*}{$\frac{\text { More than } 350 \mathbf{~ k W}}{80}$} & \multicolumn{2}{|c|}{$10-350 \mathrm{~kW}$} & \multirow{2}{*}{$\begin{array}{c}\text { Up to } \mathbf{1 0} \mathbf{k W} \\
80\end{array}$} \\
\hline \multirow{6}{*}{ Financing } & Loan, \% from investment cost & & 80 & 80 & \\
\hline & Interest rate, $\%$ & 5.0 & 5.0 & 5.0 & 5.0 \\
\hline & Loan repayment period, years & 10 & 10 & 10 & 12 \\
\hline & Equity, $\%$ from investment cost & 20 & 20 & 20 & 20 \\
\hline & Required rate of return, $\%$ & 8.0 & 8.0 & 8.0 & 8.0 \\
\hline & $\begin{array}{l}\text { Calculated discount rate based on the } \\
\text { financing structure of WPP, } \%\end{array}$ & 5.0 & 5.0 & 5.0 & 5.0 \\
\hline \multirow{4}{*}{$\begin{array}{l}\text { Support } \\
\text { measure }\end{array}$} & $\begin{array}{l}\begin{array}{l}\text { Investment subsidy, } \% \\
\text { investment cost }\end{array} \\
\end{array}$ & $30 \% / 50 \%$ & $30 \% / 50 \%$ & $30 \% / 50 \%$ & $30 \% / 50 \%$ \\
\hline & $\begin{array}{l}\text { Maximum feed-in tariff in } 2016 \text { Q1-Q2, } \\
\text { EURct/kWh }\end{array}$ & 5.6 & 6.6 & 6.6 & 6.9 \\
\hline & $\begin{array}{l}\text { Period for which feed-in tariff is applied, } \\
\text { years }\end{array}$ & 12 & 12 & 12 & 12 \\
\hline & $\begin{array}{l}\text { Share of electricity produced for which a } \\
\text { feed-in is applied, } \%\end{array}$ & 100 & 100 & 100 & 30 \\
\hline \multirow{3}{*}{ Market } & $\begin{array}{l}\text { Actual wholesale electricity price, } \\
\text { EURct/kWh }\end{array}$ & 4.2 & 4.2 & 4.2 & 4.2 \\
\hline & $\begin{array}{l}\text { Forecasted wholesale electricity price } \\
\text { during the lifetime of WPP, EURct/kWh }\end{array}$ & 5.5 & 5.5 & 5.5 & 5.5 \\
\hline & $\begin{array}{l}\text { Retail electricity price for a household } \\
\text { during the lifetime of WPP, EURct/kWh }\end{array}$ & - & - & - & 12.40 \\
\hline \multirow{5}{*}{ Other } & Corporate income tax, $\%$ & 15.0 & 15.0 & 15.0 & 15.0 \\
\hline & Personal income tax, $\%$ & 15.0 & 15.0 & 15.0 & 15.0 \\
\hline & Social security tax paid by employer, $\%$ & 30.98 & 30.98 & 30.98 & 30.98 \\
\hline & Social security tax paid by employee, $\%$ & 9.00 & 9.00 & 9.00 & 9.00 \\
\hline & Payment to the guarantee fund, $\%$ & 0.20 & 0.20 & 0.20 & 0.20 \\
\hline
\end{tabular}

\section{Research Results}

\section{Levelised Cost of Electricity}

The computed LCOE of onshore wind turbines subject to different support measures and their levels are presented in Figure 1.

$\mathrm{LCOE}_{4 \mathrm{~kW}} 10 \mathrm{~kW}$. The calculations of LCOE revealed that small-scale $(4 \mathrm{~kW}$ and $10 \mathrm{~kW})$ wind turbines could not compete in wholesale electricity market in Lithuania if support was not provided, since $\operatorname{LCOE}_{4 \mathrm{~kW}}=11.54$ EURct $/ \mathrm{kWh}$ and LCOE $10 \mathrm{~kW}=8.14 \mathrm{EURct} / \mathrm{kWh}$ and were higher than the wholesale electricity price, which stood at $\mathrm{P}_{\text {Wholesale }}=4.2 \mathrm{EURct} / \mathrm{kWh}$ during 2015 and expected to increase to $\mathrm{P}_{\text {Wholesale }}=5.5 \mathrm{EURct} / \mathrm{kWh}$ in future. Thus, support would be needed for the analysed types of WPPs. However, support level should be set at high level. Calculations demonstrated that neither $30 \%$ investment subsidy nor the selected level of the feed-in tariff would be sufficient to $4 \mathrm{~kW}$ and $10 \mathrm{~kW}$ WPP since LCOE would remain above the forecasted wholesale electricity price. However, these types of WPP could be valuable in case 70 $\%$ of their electricity would be consumed for own purposes of the household and the excess $30 \%$ of electricity would be sold via the market, since then $\mathrm{LCOE}_{4 \mathrm{~kW}, 10 \mathrm{~kW} \text { would }}$ be lower than the retail electricity price of $\mathrm{P}_{\text {Retail }}=12.40$ EURct/kWh. Seeking to promote development of smallscale WPP in Lithuania, priority should be given to the investment subsidy instead of the feed-in tariff. It was computed that $30 \%$ investment subsidy could reduce energy cost by $25 \%$ to LCOE $4 \mathrm{~kW}=8.62 \mathrm{EURct} / \mathrm{kWh}$ and LCOE $_{10 \mathrm{~kW}}=6.08$ EURct $/ \mathrm{kWh}$ while the feed-in tariff, which would be applied only to the excess electricity, would reduce energy cost up to $4 \%$ to $\operatorname{LCOE}_{4 \mathrm{~kW}}=11.24$ EURct $/ \mathrm{kWh}$ and LCOE $10 \mathrm{~kW}=7.84 \mathrm{EURct} / \mathrm{kWh}$.

$L C O E 250 \mathrm{~kW}$. Neither new nor refurbished $250 \mathrm{~kW}$ WPP would be competitive in the wholesale electricity market if no support scheme was applied. LCOE of not supported new $250 \mathrm{~kW}$ WPP would be $7.94 \mathrm{EURct} / \mathrm{kWh}$ and of a refurbished WPP -6.18 EURct $/ \mathrm{kWh} .30 \%$ investment subsidy wouldn't be attractive to investors deciding on the investment into a new $250 \mathrm{~kW}$ WPP, but investors of refurbished WPP would use the $30 \%$ investment subsidy to install WPP, since $\mathrm{LCOE}_{250 \mathrm{~kW}}$, Refurbished $=4.61$ EURct $/ \mathrm{kWh}$ while the expected wholesale electricity price would be $\mathrm{P}_{\text {Wholesale }}=5.5 \mathrm{EURct} / \mathrm{kWh}$. Due to high investment cost, $50 \%$ investment subsidy would be sufficient to motivate the investor to build a new $250 \mathrm{~kW}$ WPP, since $\mathrm{LCOE}_{250 \mathrm{~kW}, \mathrm{New}}=4.78 \mathrm{EURct} / \mathrm{kWh}$. 6.6 EURct $/ \mathrm{kWh}$ feedin tariff would make a refurbished $250 \mathrm{~kW}$ WPP economically attractive. Gross profit (the difference between the forecasted wholesale electricity price and LCOE) would be 0.11 EURct $/ \mathrm{kWh}$. However, the selected level of the feed-in tariff wouldn't be the investor motivating in a case of building a new $250 \mathrm{~kW}$ WPP, since LCOE $250 \mathrm{~kW}$, New $=7.25 \mathrm{EURct} / \mathrm{kWh}$.

$L C O E_{2000 \mathrm{~kW}}$. Although so far a $2000 \mathrm{~kW}$ WPP couldn't generate electricity below the wholesale electricity price, however, $\mathrm{LCOE}_{2000 \mathrm{~kW}}=5.0 \mathrm{EURct} / \mathrm{kWh}$ is approaching the $\mathrm{P}$ wholesale $=4.2 \mathrm{EURct} / \mathrm{kWh}$ in 2015 and the forecasted wholesale electricity price $\mathrm{P}$ Wholesale $=5.5$ EURct $/ \mathrm{kWh}$. Both $30-50 \%$ investment subsidy and a maximum feed-in tariff of $5.6 \mathrm{EURct} / \mathrm{kWh}$ would prove the business case for the private investor. Subject to a feedin tariff, the LCOE $2000 \mathrm{~kW}$ would be $4.96 \mathrm{EURct} / \mathrm{kWh}$ or by $10 \%$ lower than the forecasted wholesale electricity price. $30 \%$ investment subsidy would allow reducing the $\mathrm{LCOE}_{2000 \mathrm{~kW}}$ to $3.83 \mathrm{EURct} / \mathrm{kWh}$ and $50 \%$ investment subsidy - to 3.03 EURct $/ \mathrm{kWh}$. Thereby, lower than the forecasted wholesale electricity price, LCOE leave the room for the investor to earn profit. 


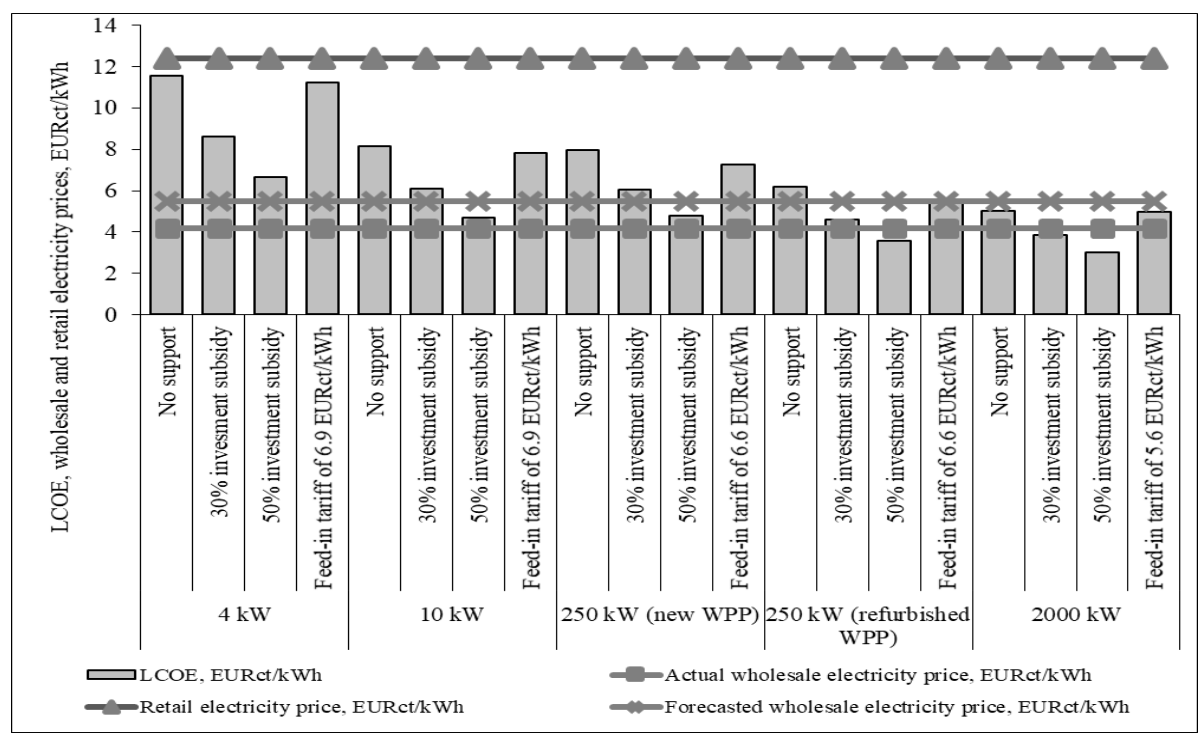

Figure 1. LCOE of Onshore Wind Turbines Subject to Different Support Measures and their Levels (Own Computations)

\section{Profit from Electricity Production and Selling}

The computed profit from electricity production and selling subject to different support measures, their levels and type of WPP are presented in Figure 2 and Figure 3.

Profit of $4 \mathrm{~kW}$ and $10 \mathrm{~kW}$ WPP Figure 2 demonstrates profit earned by the owners of $4 \mathrm{~kW}$ and $10 \mathrm{~kW}$ WPPs during their life-time subject to no support, feed-in tariff of 6.9 EURct $/ \mathrm{kWh}$ and $30-50 \%$ investment subsidy. With reference to data, presented in Figure 2, $4 \mathrm{~kW}$ wind turbine would be unprofitable without support. On the contrary, its losses would amount to 1.06 thousand EUR. A maximum feed-in tariff would make a $4 \mathrm{~kW}$ WPP suffer losses of 0.8 thousand EUR. $30 \%$ and $50 \%$ investment subsidy would allow $4 \mathrm{~kW}$ WPP earn profit, which would be 1.5 thousand EUR and 3.2 thousand EUR, respectively. $10 \mathrm{~kW}$ wind turbine even without support would be profitable. Subject to $30 \%$ and $50 \%$ investment subsidy and a maximum feed-in tariff the profit would be 9.7 thousand EUR, 12.9 thousand EUR and 5.7 thousand EUR, respectively.

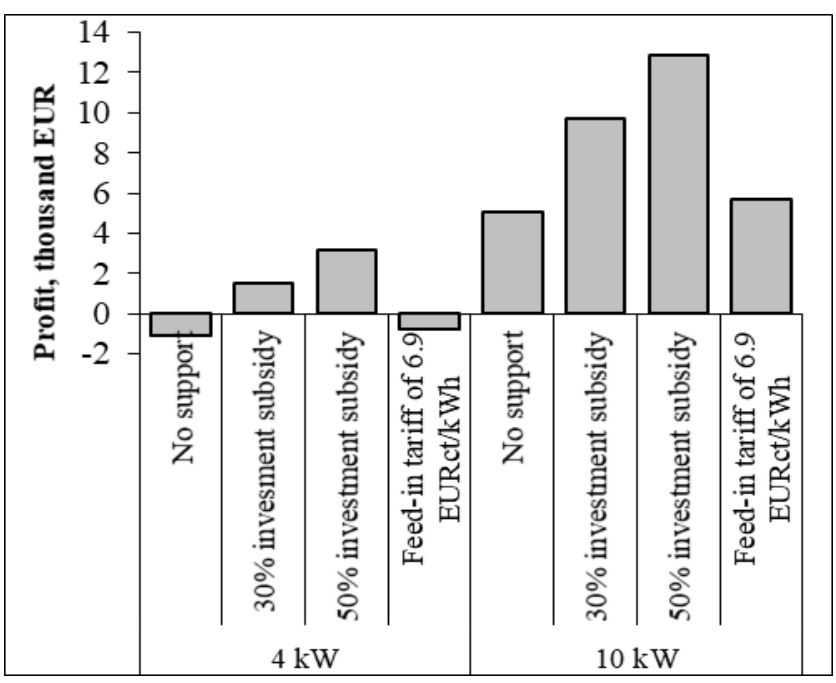

Figure 2. Profit of $4 \mathrm{~kW}$ and $10 \mathrm{~kW}$ onshore wind turbines subject to different support measures and support levels (own computations)
Profit of $250 \mathrm{~kW} W P P$. As it is shown in Figure 3, electricity production in new $250 \mathrm{~kW}$ WPP would not be profitable in Lithuania when a feed-in tariff and $30 \%$ investment subsidy was given. Subject to $50 \%$ investment subsidy, the profit would be 55.5 thousand EUR during the life-time of 25 years of a new $250 \mathrm{~kW}$ WPP. In case a refurbished $250 \mathrm{~kW}$ WPP would be built, the losses of 42.5 thousand EUR would be suffered when no support was given. Subject to $30 \%$ and $50 \%$ investment subsidy and a feed-in tariff, the profit would be 55.6, 120.9 and 6.6 thousand EUR of a refurbished $250 \mathrm{~kW}$ WPP, respectively.

Profit of $2000 \mathrm{~kW}$ WPP. Calculations showed (see Figure 3) that during the life-time of 25 years a $2000 \mathrm{~kW}$ WPP would earn profit even no support was provided. The generator would earn profit, which would amount to 428.1 thousand EUR if a feed-in tariff of 5.6 EURct/kWh was provided or 1323.4-1953.4 thousand EUR if $30-50 \%$ investment subsidy was given.

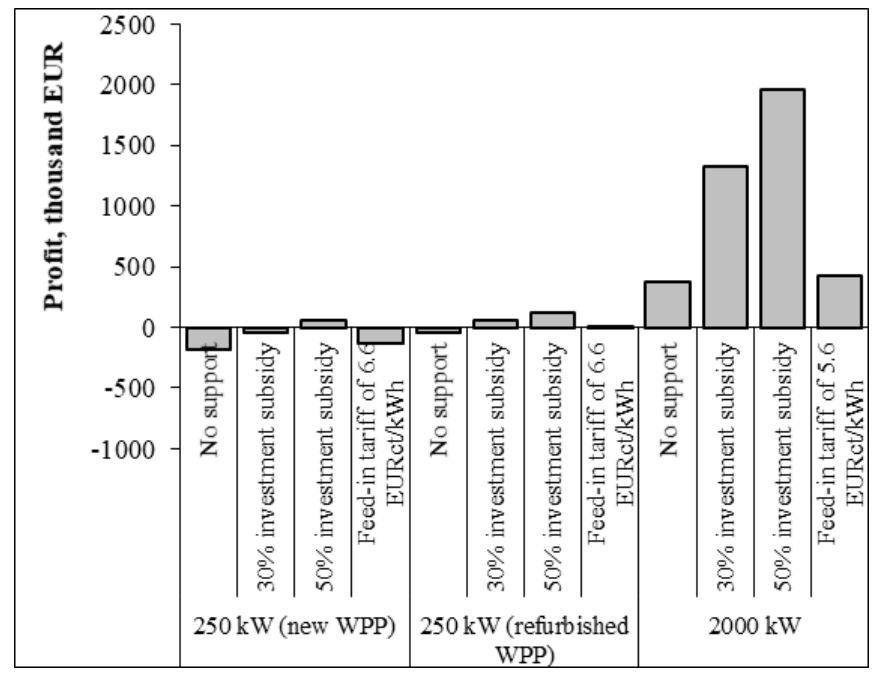

Figure 3. Profit of $250 \mathrm{~kW}$ and $2000 \mathrm{~kW}$ onshore wind turbines subject to different support measures and support levels (own computations) 


\section{Income-Based Taxes}

Computations of income-based taxes during the lifetime of WPP are presented in Table 2.

During its lifetime, $4 \mathrm{~kW}$ wind turbine would generate 1.0 thousand EUR of income-based taxes. Payments to social security fund would account to $70 \%$ and personal income tax $-30 \%$ of income-based taxes. Taxes collected from the owner of $10 \mathrm{~kW}$ WPP would be by $90 \%$ higher. The owner of a new $250 \mathrm{~kW}$ WPP could pay 42.8 thousand EUR income-based taxes, but the owner of a refurbished $250 \mathrm{~kW}$ WPP would pay by $34 \%$ less income-based taxes. Income-based taxes paid by the owner of $2000 \mathrm{~kW}$ WPP would be by 5 times higher than those, which would be collected from the owner of a new $250 \mathrm{~kW}$ WPP.

Table 2

Income-Based Taxes Collected During the Lifetime of WPP (Own Computations)

\begin{tabular}{|c|c|c|c|c|c|}
\hline & $4 \mathrm{~kW}$ & $10 \mathrm{~kW}$ & $\begin{array}{c}250 \mathrm{~kW}(\text { new } \\
\text { WPP) }\end{array}$ & $\begin{array}{c}250 \mathrm{~kW} \\
\text { (refurbished WPP) }\end{array}$ & $2000 \mathrm{~kW}$ \\
\hline Payments to social security fund, thousand EUR & 0.7 & 1.4 & 31.1 & 20.5 & 155.3 \\
\hline Personal income tax, thousand EUR & 0.3 & 0.5 & 11.6 & 7.7 & 58.0 \\
\hline Total, thousand EUR & 1.0 & 1.9 & 42.8 & 28.2 & 213.3 \\
\hline
\end{tabular}

\section{$\mathrm{CO}_{2}$ savings}

Electricity production in WPP would contribute to $\mathrm{CO}_{2}$ emissions. It was computed that a $2000 \mathrm{~kW}$ WPP would save $48 \mathrm{kt}$ of $\mathrm{CO}_{2}$ during its life-time. Discounted value in monetary terms would be 202.66 thousand EUR. $\mathrm{CO}_{2}$ emission savings of a new $250 \mathrm{~kW}$ WPP could be $4.68 \mathrm{kt}$. This is by $36 \%$ more than $\mathrm{CO}_{2}$ savings of a refurbished $250 \mathrm{~kW}$ WPP. Discounted value in monetary terms would be 19.79 thousand EUR and 16.1 thousand EUR, respectively. $4 \mathrm{~kW}$ and $10 \mathrm{~kW}$ WPP would save 47.9 $\mathrm{tCO}_{2}\left(0.22\right.$ thousand EUR) and $125.8 \mathrm{tCO}_{2}(0.59$ thousand EUR) during the life-time of WPP, respectively.

\section{Electricity Import Substitution}

Taking into account the price of imported electricity and possibility of wind power to substitute it, it was computed that import position of the trade balance could be reduced by 786.5 thousand EUR and 563.1 thousand EUR if a new and refurbished $250 \mathrm{~kW}$ WPP was installed, respectively, and by 6.9 million EUR if a $2000 \mathrm{~kW}$ WPP was constructed.

\section{Policy Implications and Conclusions}

The paper demonstrates the application of microeconomic analysis method for the assessment of wind power technologies and formation of RES support policy in Lithuania.

RES support policy decision making should be based on economic assessment principles. Namely, both cost (cost of energy produced by RES technologies) and benefits (profit, electricity import substitution, $\mathrm{CO}_{2}$ savings, taxes collected) of RES technologies should be evaluated. Based on the evaluations, RES support policy related decisions should be accepted.

Short-, medium- and long-term economic objectives should be taken into account when developing and transforming the principles of RES promotional measures and establishing a well-harmonized RES support scheme.

Based on the results of LCOE computations, the authors argue that the short-term (up to 2020) promotional schemes for wind power technologies should be linked to the utilization of Structural Funds (namely, an investment subsidy is a good promotional measure). A feed-in tariff is an attractive support measure since it could make wind power technologies competitive in the market. However, longer term promotional schemes that would cover both implementation of strategic importance energy projects and all types of RES are essential.

The measures of medium-term RES promotional schemes should be adjusted and updated by refusing incentives that apparently distort relations in the market. In the area of wind power sector, the role of the Government should be limited to ensuring and establishing the infrastructure for supply of wind power (i.e. improvement and construction of electricity networks).

Adoption of support schemes for promotion of energy from small-scale wind power plants, mass manufacturing of which would be possible in Lithuania, is of high importance. The research results demonstrate that although presently small-scale WPPs are not economically competitive, however, these plants could be efficient in remote areas beyond the city.

The results of computations of profit, income-based taxes, electricity import substitution disclosed economic benefits from wind power sector development in Lithuania. Under the assumptions taken it could be argued that wind power support measures are capable to bring economic benefits to the country's economy since sufficient amount of support increases profits, taxes collected and reduces electricity import.

The results of computation of $\mathrm{CO}_{2}$ savings demonstrate that implementation of wind technologies provides environmental benefit in terms of $\mathrm{CO}_{2}$ emissions saved. Subject to increasing price of $\mathrm{CO}_{2}$ emission, environmental benefits in monetary terms increase.

In Lithuania, the major part of equipment is imported, but if the number of similar projects increases and this process gains a large scope, it is likely that some of the equipment will be produced locally. This potential positive effect of continuing support could be missed by the model based on microeconomic indicators. On the other hand, experience gained in Lithuania and foreign countries experience could help make and aggregate estimate of possible cumulative effect which could be expected in case of utilization of RES in the country.

It is necessary to have in mind that every country is in different situation of economic development. Therefore, the mechanical copy-paste approach of the economic 
Valentinas Klevas, Viktorija Bobinaite, Mantas Marciukaitis, Dalius Tarvydas. Microeconomic Analysis for the Formation ...

policy is a negative phenomenon. Wind power support policy does not have to contradict the Lithuanian strategic aim, which is to reduce country's dependency upon the single energy supplier. In this respect, large-scale onshore and offshore WPPs are a promising scenario for development of wind energy sector in the country.

One of the biggest technical challenges of wind energy utilization in comparison with traditional forms of electricity generation is that the output of WPPs directly depends on the volatility of the wind. For this reason, power system should maintain adequate power reserve to compensate the fluctuation of wind speed. Therefore, additional burden of electricity balancing is put on the power system, especially if the wind power comprises a significant share of the country's power system.

\section{References}

Acker, T. L., Williams, S. K., Duque, P. N., Brummels, G., \& Buechler, J. (2007). Wind resource assessment in the state of Arizona: Inventory, capacity factor, and cost. Renewable Energy, 32(9), 1453-1466. https://doi.org/10.1016/j.ren ene.2006.06.002

Ayres, R. U., \& Gowdy, J. M. (1999). Viewpoint: Weak versus strong sustainability. 18 pages.

Al-mulali, U., Fereidouni, H.; Lee, Y., \& Sab, Ch. (2013). Examining the bi-directional long run relationship between renewable energy consumption and GDP growth. Renewable and Sustainable Energy Reviews, 22, 209-222. https://doi.org/10.10 16/j.rser.2013.02.005

Analysis of wind power development possibilities (2009). Report of the 1st stage. Kaunas University of Technology, Lithuanian Energy Institute. 149 p.

Apergis, N., \& Payne, J. E. (2010a). Renewable energy consumption and economic growth: Evidence from a panel of OECD countries. Energy Policy, 38(1), 656-660. https://doi.org/10.1016/j.enpol.2009.09.002

Apergis, N., \& Payne, J. E. (2010b). Renewable energy consumption and growth in Eurasia. Energy Economics, 32(6), 13921397. https://doi.org/10.1016/j.eneco.2010.06.001

Apergis, N., \& Payne, J. E. (2011). The renewable energy consumption-growth nexus in Central America. Applied Energy, 88(1), 343-347. https://doi.org/10.1016/j.apenergy.2010.07.013

Bobinaite, V., \& Tarvydas, D. (2014). Financing instruments and channels for the increasing production and consumption of renewable energy: Lithuanian case. Renewable and Sustainable Energy Reviews, 38, 259-276. https://doi.org/10.101 6/j.rser.2014.05.039

Bobinaite, V., Juozapaviciene, A., \& Konstantinaviciute, I. (2011). Assessment of Causality Relationship between Renewable Energy Consumption and Economic Growth in Lithuania. Inzinerine Ekonomika-Engineering Economics(5), 510-518. https://doi.org/10.5755/j01.ee.22.5.969

Chien, T., \& Hu, J. L. (2007). Renewable energy and macroeconomic efficiency of OECD and non-OECD economies. Energy Policy, 35(7), 3606-3615. https://doi.org/10.1016/j.enpol.2006.12.033

Chien, T., \& Hu, J. L. (2008). Renewable Energy: An Efficient Mechanism to Improve GDP. Energy Policy, 36, 3045-3052.

https://doi.org/10.1016/j.enpol.2008.04.012

Ciarreta, A., Gutierrez-Hita, C., \& Nasirov, Sh. (2011). Renewable energy sources in the Spanish electricity market: Instruments and effects. Renewable and Sustainable Energy Reviews, 15, 2510-2519. https://doi.org/10.1016/j.rser.2011.01.023

Domac, J., Richards, K., \& Risovic, S. (2005). Socio-economic drivers in implementing bioenergy projects. Biomass and Bioenergy, 28(2), 97-106. https://doi.org/10.1016/j.biombioe.2004.08.002

EC. (2013). European Commission guidancefor the design of renewable energy support schemes. Commission staff working document.

European Commission (2014). State aid: Commission adopts new rules on public support for environmental protection and energy. Available from internet: http://europa.eu/rapid/press-release_IP-14-400_en.htm.

European wind energy association (EWEA). (2009). The economics of wind energy.

Fang, Y. (2011). Economic welfare impacts from renewable energy consumption: The China experience. Renewable and Sustainable Energy Reviews, 15(9), 5120-5128. https://doi.org/10.1016/j.rser.2011.07.044

Feasibility study on the integration of renewable energy power plants to the 330-110 kV transmission grid till 2030 (2014). Kaunas University of Technology, SC Litgrid, Vilnius.

Gass, V., Schmidt, J., Strauss, F., \& Schmid, E. (2013). Assessing the economic wind power potential in Austria. Energy Policy, 53, 323-330. https://doi.org/10.1016/j.enpol.2012.10.079

Yildirim, E., Sarac, S., \& Aslan, A. (2012). Energy consumption and economic growth in the USA: Evidence from renewable energy. Renewable and Sustainable Energy Reviews, 16(9), 6770-6774. https://doi.org/10.1016/j.rser.2012.09.004

Implementation Plan for National Strategy on Development of Renewable Energy Sources during years 2010-2015 (2010). Available from internet: http://www3.lrs.lt/pls/inter3/dokpaieska.showdoc_l?p_id=377162. 
IRENA. (2012). Power sector. Volume 1. Available from internet: http://www.irena.org/DocumentDownloads/Public ations/RE_Techno logies_Cost_Analysis-WIND_POWER.pdf.

Jaramillo, O. A., Saldana, R., \& Miranda, U. (2004). Wind power potential of Baja California Sur, Mexico. Renewable Energy, 29(13), 2087-2100. https://doi.org/10.1016/j.renene.2004.03.004

Klevas, V. (2015). Justification of long - term economic policy of renewable energy sources. Nova Science Publischers. 184 p.

Law on Renewable Energy Sources. (2011). Available from internet: http://www3.lrs.lt/pls/inter3/dokpaieska.show doc_1?p_id=398874.

Lithuanian National Renewable Energy Action Plan. (2009). Available from internet: http://ec.europa.eu/energy/renewa bles/action_plan_en.htm.

Lu, X., Tchou, J., McElroy, M. B., \& Nielsen, Ch. P. (2011). The impact of Production Tax Credits on the profitable production of electricity from wind in the U.S. Energy Policy, 39(7), 4207-4214. https://doi.org/10.1016/j.enpol.2011.04.034

Magnani, N., \& Vaona, A. (2013). Regional spillover effects of renewable energy generation in Italy. Energy Policy, 56, 663671. https://doi.org/10.1016/j.enpol.2013.01.032

Menegaki, A. N. (2011). Growth and renewable energy in Europe: A random effect model with evidence for neutrality hypothesis. Energy Economics, 33(2), 257-263. https://doi.org/10.1016/j.eneco.2010.10.004

Strategy for Development of Renewable Energy. (2010). Available from internet: http://www3.lrs.lt/pls/inter3/dokp aieska.showdoc_1?p_id=376097.

Talberg, A. (2014). Support for renewable energy. Available from internet: http://www.aph.gov.au/About_Parliament/Parliam entary_Departments/Parliamentary_Library/pubs/BriefingBook44p/RenewableEnergy.

The article has been reviewed.

Received in November, 2015; accepted in April, 2018. 